\title{
New directions in water resources management: The role of water pricing policies
}

\author{
Eva Iglesias and María Blanco
}

\begin{abstract}
Water resources will face increasing competition and higher environmental concerns during this century. To meet these challenges, the new Water Framework Directive has drawn up an integrated framework and established the basic principles for a sustainable water policy in the European Union. The introduction of water prices reflecting the true cost of irrigation is one of its most innovative components. In this paper, a positive mathematical programming model is developed to assess the environmental and socioeconomic impacts of water pricing policies in Spanish irrigated lands. The model interface allows friendly use and easy replication in a large number of irrigation districts, selected throughout the Spanish territory. The model results show the impact on environmental indicators, water consumption, cropping patterns, technology adoption, labor, farmers' income, and the water agency revenues when different scenarios of cost recovery are considered. It is argued that this modeling approach may be used as a management tool to assist in the implementation of the cost recovery approach of the new Water Framework Directive.
\end{abstract}

\section{Introduction}

Water resources managément will face increasing scarcity, growing competition, and rising environmental concerns in this century. Yet during the late 20th, century the amount of research in water institutions has been scarce in comparison with other aspects of water resources research. The creation of innovative water institutions and other contributions from the social sciences have been signaled as a critical issue for effective water management in the 21st century [National Research Council, 2001].

The use of market-based instruments and having the users or polluters pay principle to achieve environmental goals is gaining wider acceptance in many countries. According to Jones [2003], water problems are expected to be a major constraint on sustainable development in some countries during the next few decades, and water pricing is a key tool for overcoming this constraint.

In Europe, these issues are addressed by the Water Framework Directive (WFD) which developed an integrated framework for all water resources and aims at achieving a good status for both ground and surface water by 2015. The promotion of water pricing policies and the implementation of a cost recovery approach in the management of water resources is one of the most innovative elements introduced by this directive which establishes the basic principles for a sustainable water policy in the European Union [European Commission, 2000].
European Union member states shall ensure that water pricing policies provide adequate incentives to use water resources efficiently and thereby contribute to the environmental objectives. Article 9 of the WFD requires that member states take into account the principle of cost recovery of water services, including environmental and resource costs. In doing so, member states may have to regard to the social, environmental, and economic effects of implementing the cost recovery policy as well as the geographic and climatic conditions of the regions.

While the implementation of water pricing policies does not pose substantial problems with industrial, hydroelectric, and urban users, it has become a highly controversial issue when it comes to agricultural users [Organisation for Economic Cooperation and Development (OECD), 2001]. In Australia, water price reforms are advanced in the urban sector, whereas there is large opposition to reforms in the rural agricultural sector [Musgrave, 2000]. In OECD countries, pricing structures for municipal and industrial water services increasingly reflect the full cost of water services, but irrigation water remains heavily subsidized, which often encourages inefficient use of scarce water resources. Even taking into account different water quality needs and conveyance standards, water prices are significantly lower for agriculture than for other use sectors $[O E C D, 2001]$.

This is particularly the case in most Mediterranean countries which share several common features. First, irrigated agriculture accounts for a large share of the total farming production and still plays an important role in the economic activity within some areas. Second, agriculture has traditionally been, and still is, the main water user. This is the case in Spain, where agricultural users account for $80 \%$ of total water consumption and therefore become a key 
stakeholder in the water policy arena. Third, agricultural intensification has led to a significant increase in water abstraction and fertilizer use, giving rise to growing environmental problems. These include lower groundwater and river flow levels as a direct result of water abstraction; increased nitrate, phosphate, and pesticide leaching; and the pollution of ground and surface water.

Since the 1992 Dublin Conference, when governments recognized the need to manage water as an economic good, water pricing policies are increasingly seen as a means of promoting water efficiency and enhancing sustainability. However, the design and implementation of appropriate water charges has been and still is a highly controversial issue [Centre for International Economics, 2004; Johansson et al., 2002]. The design and application of price-based instruments is critical because the flow of water through a basin is complex and uncertain, and it provides a wide scope for externalities, market failure, and high transaction costs.

In practice, water pricing is expected to (1) provide a source of income to water suppliers to guarantee financial viability and adequate maintenance of the water supply system, (2) reduce demand and guarantee a sustainable use of water resources, and (3) reallocate water from lowvalue to high-value uses. Priorities among objectives must be defined in order to design an effective water charge system [Cornish et al., 2004].

While there is a reasonable consensus that water prices may be an efficient mechanism for achieving the financial sustainability of water supply systems, a number of questions arise, notably with regard to environmental issues such as nonpoint source pollution, its effectiveness as a demand management measure, its social acceptability, and its political feasibility.

Water reforms in the irrigated sector are already under way but at a slow pace $[O E C D, 2001]$. Practical difficulties of enforcement and the lack of political will to impose higher costs on farmers have been signaled as factors that hamper the implementation of water prices [Cornish et al., 2004]. The relative performance and efficiency of alternative pricing methods may be highly dependent on their respective implementation cost, such as those arising from the need for information and metering [Tsur and Dinar, 1997; Tsur, 2000]. However, very little empirical evidence or methodology exists for evaluating the practical limitations of various implementation costs [Johansson et $a l ., 2002]$.

Several authors contend that other policy options such as water markets may be a more effective means of signaling the scarcity value of water and reallocating water to more efficient uses [Cornish et al., 2004]. However, the circumstances under which water markets are viable remain an open question, particularly when environmental externalities are present. Some authors have argued that command and control allocation systems based on quotas may be a better way to curtail water demand and to signal the practical limitations for volumetric pricing in developing countries [Johansson et al., 2002]. On the contrary, Brennan et al. [2007] and Iglesias et al. [2007] report important economic efficiency losses because of command and control measures in the urban and agricultural sector, respectively. Nonetheless, it has been noted that water pricing does not happen in a void and that it needs to be embedded and evaluated within the existing institutional framework [de Fraiture and Perry, 2002]. Thus, what is at stake is the appropriate combination between incentive-based and regulatory approaches.

To sum up, the implementation of the cost recovery approach implies an important change in water policy and shows the need for carefully defined water pricing criteria taking into account environmental-, socio-economic-, and regional-specific impacts. This new institutional context increases the need to develop economic management tools to assess the design and evaluation of water pricing criteria among and across different water users.

However, most existing empirical work refers to specific areas, making it difficult to draw general conclusions. Thus, the objective of this paper is to develop a metamodel that can be used to assess the implementation of the WFD and the design of efficient water pricing criteria within the farming sector.

The development of this metamodel presents several challenges. First, this simulation tool should accommodate the wide range of different situations that can be found throughout the Spanish irrigation systems. Second, it should be adapted to exploit available statistical data sources. Third, it should be user friendly and allow easy replication in a large number of irrigation districts. Fourth and most important, it should convey useful information to the policy maker and assess the design of efficient water pricing criteria. The model is tested in two irrigation districts with different climatic, agronomic, and economic characteristics. Detailed results are presented along with a discussion of how this modeling tool can be used to anticipate the social, economic, and environmental impacts of a volumetric water charge.

\section{Background}

Many empirical studies show that farmers' response to water pricing and its effectiveness are highly dependent on site-specific variables ranging from natural conditions to political and institutional settings, making it necessary to design policy mechanisms accordingly [Johansson et al., 2002; Varela-Ortega et al., 1998]. De Fraiture and Perry [2002] contend that water-rationing practice already in place prior to the introduction of pricing has an important bearing on its effectiveness as a demand management tool.

Given the complex nature of most environmental problems, Xabadia et al. [2004] argue that water pricing policies that aim at nonpoint pollution should be site specific and time dependent. The authors analyze the case of irrigated cotton produced in the San Joaquin Valley in California and determine the socially optimal water price in the presence of waterlogging.

Water pricing may also play an important role in technology adoption. However, other factors such as land quality, agronomic considerations, and water scarcity strongly determine the choice of irrigation technology [Caswell and Zilberman, 1985; Green et al., 1996 and Varela-Ortega et al., 1998].

There is a great deal of controversy surrounding the empirical estimates of water elasticity in irrigation and its interpretation. Several authors contend that water elasticity is low, and thus the implementation of water charges at 
moderate levels will not be effective in terms of water savings [de Fraiture and Perry, 2002; Johansson et al., 2002; Cornish et al., 2004]. However, there seems to be evidence that farmers' response and thus the relative magnitude of water elasticity are empirical questions that strongly depend on agronomic, regional, and institutional factors [Varela-Ortega et al., 1998; Gómez-Limón and Riesgo, 2004; Johansson et al., 2002].

In a recent study, Schoengold et al. [2006] highlight the need for sound estimates of water demand elasticity and find that agricultural water demand is somewhat more elastic with respect to price than indicated by previous studies. The authors observed a natural experiment in the form of rate reform in the Arvison Edison Water storage district near Los Angeles, California and conclude that a change in water rates may have a larger effect on water allocation than previously assumed.

Scheierling et al. [2006] try to explain differences in water elasticity estimates drawn from 24 studies reported in the United States since 1963 and conclude that empirical methods may underestimate water price elasticity since they do not account for potential endogenous responses at the farm level. Econometric approaches and particularly mathematical programming methods lead to higher elasticity estimates.

An important limitation to site-specific policy assessment is that most existing works require exhaustive and expensive fieldwork and data collection and/or focus on a more or less limited empirical application. Varela-Ortega et al. [1998], for instance, conduct comprehensive field data to assess the socio-economic impact of water pricing policies in several irrigation districts. Iglesias et al. [2003] develop a detailed model to investigate farmers' adaptation strategies and the economic costs imposed by drought spells in vulnerable areas. In other areas, behavioral psychology research models have established the influence of knowledge and attitudes in farmers' decision making [Vogel, 1996; Willock et al., 1999; Kuehne and Bjornlund, 2007; Maybery et al., 2005], suggesting that farmers' values should be taken into account to formulate an effective conservation policy. Gómez-Limón and Riesgo [2004] characterize farmers' attitudes and analyze differential responses to water prices.

Most policy analyses in the agricultural sector have traditionally relied on programming methods. This approach is based on simulation models that reproduce farmers' decisions assuming profit-maximizing behavior and allowing ex ante analyses of policy changes on a detailed and disaggregated scale. One of the most severe criticisms of conventional mathematical programming is that the modeler is obliged to add arbitrary constraints in order to avoid overly specialized solutions and so that the results are calibrated to fit the observed situation. Both characteristics limit the potential of traditional farming models to perform policy evaluation in a relatively large number of areas.

In this context, the positive mathematical programming method (PMP) overcomes some important limitations of traditional linear programming and has opened a promising research frontier [Howitt, 1995]. Most important in this approach is that it recovers additional information implicit in observed data on farmers' land allocation decisions, allowing the model to be automatically calibrated to the base situation. It is assumed that unobservable characteristics or costs that condition farmers' behavior are implicit in observed data on farmers' land allocation decisions. In this way, the need to introduce ad hoc and nonempirically justified calibration constraints that tie the model to the observed situation is avoided. Furthermore, the resulting model is able to respond smoothly to changes in prices or constraints.

This methodology has been very widely welcomed among policy modelers and has given rise to an active research agenda within different fields. Paris and Howitt [1998] and Heckelei and Wolff [2003] extend the original approach to recover a flexible cost function when there are several observations on farmers' allocation decisions applying maximum entropy criteria. Heckelei and Britz [2000] also use an econometric criteria and develop a crosssectional estimation procedure to deal with multiple data points. This approach has established a nexus between programming and econometric techniques.

While the standard method estimates cost or production functions for each land use activity separately, $R \ddot{o} h m$ and Dabbert [2003] consider in their modeling framework the elasticity of substitution among interrelated crops and develop an empirical regional production model to evaluate agrienvironmental programs. Another recent contribution to PMP is the work of Preckel et al. [2002], who build up a PMP model that permits existing information to be specified on both primal- and dual-variable levels. The authors illustrate their method through an evaluation of the impacts of market resistance to genetically modified grains.

[27] In this paper, the PMP approach is adopted to analyze the critical impact of water pricing criteria on the different irrigation communities that compose a river basin. One serious limitation in PMP is that model activities are restricted to those existing in the observed situation. Thus, it does not allow the consideration of technology adoption or new activities, even when these might become plausible strategies under certain policy changes. In this paper, the standard approach is extended, and a cost transfer method is proposed to incorporate the possibility of water-saving technology adoption when simulating farmers' response to water pricing policies. This metamodel contains an automatic calibration procedure that facilitates easy replication in a large number of irrigation districts to analyze farmers' response to water pricing policies. This feature was not possible in "traditional" mathematical programming models, where the modeler played a crucial role in the calibration step.

Integrating environmental goals in economic models is not an easy task. A major limitation related to agriculture and water quality is the lack of well-established economic relationships between agricultural practices and water quality. Nonpoint source pollution is a dynamic and site-specific process. Emissions from nonpoint sources are either difficult to observe, or their observation is prohibitively expensive. Hence, the use of agrienvironmental indicators $[O E C D, 2001]$ is the most common method of integrating environmental concerns in economic analysis. Although the efficiency of water prices in addressing nonpoint source pollution has been questioned [Martinez and Albiac, 2004], water prices may have an indirect effect on fertilizer use. 
Thus, the sign and magnitude of the impact of water prices on fertilizer use deserves attention.

Water pollution caused by nitrates has been reported as one of the main environmental problems associated with agricultural activities [Scheierling, 1995]. Nitrates are highly soluble and migrate easily into groundwater through the soil, making it difficult to establish a link between nitrogen supply and water pollution. Given the lack of information and the complex and dynamic soil-water relationship, one proxy method for dealing with water pollution is to estimate the amount of fertilizer applied within the crop pattern [European Environmental Agency, 2005; OECD, 2001; Scheierling, 1995]. Although indeed partial and limited, this indicator may reveal pressures and trends relevant to the nonpoint water pollution problem.

\section{Methodology}

Given that water delivery costs and the impact of water prices may be highly heterogeneous throughout a given river basin, the assessment of water policies should be able to differentiate and characterize policy impacts at a detailed and disaggregated level. To this end, a model that simulates farmers' behavior and water resource use in response to scenarios of volumetric water tariffs was developed and applied to a large number of heterogeneous irrigated areas.

Data requirements and easy replication were decisive factors in selecting the methodological framework. The model aims at exploiting information in available statistical data sources, and positive mathematical programming, first developed by Howitt [1995], appeared as a suitable option. Compared to conventional mathematical programming, the main advantages of this approach are the exact representation of the reference situation, lower data requirements, and a smooth response of model results to continuous changes in exogenous parameters when the model is used for analysis of policy changes. Also important to our objectives is that by applying the PMP approach, it was possible to build an automatic calibration procedure of the model reflecting the observed cropping pattern in each irrigation district and to facilitate easy replication through the different areas of a river basin on a detailed scale.

One of the main disadvantages of positive mathematical programming is that options available to the farmers are limited to the observed activities in the base year situation. To overcome this difficulty, the standard PMP approach is extended in order to allow the incorporation of new production activities and irrigation technologies. A cost transfer approach is proposed in order to simulate the adoption of new irrigation technologies and the switch from irrigated to dry-land crops.

We follow the standard PMP method to calibrate mathematical programming models to observed activity levels involving a two-step procedure for implementation [Howitt, 1995; de Frahan et al., 2005]. In the first step, a conventional linear programming model is bounded by observed activity levels in the irrigation district introducing a set of calibration constraints. In the second step, dual values associated with the calibration constraints allow recovery of a nonlinear objective function such that once the calibration constraints are removed, the new program- ming model reproduces almost exactly the observed activity levels.

The calibration model can be compactly written (subindex $j=1, \ldots m$ denotes the crop type, subindex $r=$ $1, \ldots s$ denotes the irrigation technique, and subindex $i=$ $1, \ldots n$ denotes the resource type)

$$
\begin{gathered}
\operatorname{Max} Z=\sum_{j} \sum_{r}\left(p_{j} y_{j r}-c_{j r}\right) x_{j r} \\
\text { subject to } \sum_{j} \sum_{r} a_{i j r} x_{j r} \leq b_{i} ; \forall i, j, r \\
x_{j r} \geq 0 ; \forall j, r \\
x_{j r} \leq x_{j r}^{0}(1+\varepsilon) ; \forall j, r,
\end{gathered}
$$

where $Z$ denotes the objective function value and represents farmers' revenue; $c_{j r}$ is the variable cost of crop $j$ grown with irrigation technique $r ; x_{j r}$ represents the area devoted to crop $j$ under irrigation technique $r ; p_{j}$ and $y_{j r}$ are (expected) output prices for crop $j$ and yields for crop $j$ under irrigation technique $r$, respectively; $a_{i j r}$ represents coefficients in resource/policy constraints; $b_{i}$ represents available quantity of resource $i ; x_{j r}^{0}$ denotes observed areas for crop $j$ and irrigation techniques $r$; and $\varepsilon$ is a small positive number.

The objective function maximizes net farm income. Net income is defined as total sales value minus irrigation costs and other variable costs. Resource constraints include constraints on total cropland available, total irrigation water available, and agricultural policy.

The addition of calibration constraints forces the optimal solution of the linear programming model to reproduce almost perfectly the observed base year activity levels $x_{j r}^{0}$. The solution of the linear model provides the dual values associated with the calibration constraints, which give indirect information about the cost functions.

First-order conditions for profit maximization are

$$
\begin{gathered}
\left(p_{j} y_{j r}-c_{j r}-\sum_{i=1}^{m} \lambda_{i} a_{i j r}-\mu_{j r}\right)_{x_{j r}=x_{j r}^{*}}=0 \quad \forall j, r / x_{j r}^{*} \neq 0 \\
\left(b_{i}-\sum_{j=1}^{n} a_{i j r} x_{j r}\right)_{x_{j r}=x_{j r}^{*}}=0 \quad \forall i / \lambda_{i} \neq 0 \\
\left(x_{j r}^{0}(1+\varepsilon)-x_{j r}\right)_{x_{j r}=x_{j r}^{*}}=0 \quad \forall j, r / \mu_{j r} \neq 0,
\end{gathered}
$$

where $\lambda_{i}$ is the dual value for the $i$ resource, and $\mu_{j r}$ represents the dual values associated with the calibration constraints. The first condition (5) can be rewritten as

$$
\sum_{i=1}^{n} \lambda_{i} a_{i j r}=p_{j} y_{j r}-c_{j r}-\mu_{j r}^{\prime} .
$$


Table 1. General Data for the Canal de Montijo and Bajo Guadalquivir Irrigation Districts

\begin{tabular}{lcc}
\hline & Canal de Montijo & Bajo Guadalquivir \\
\hline Total area (ha) & 10,087 & 47,883 \\
Irrigation method (\%) & & \\
$\quad$ Surface irrigation & 87.3 & 90.8 \\
Drip irrigation & 6.2 & 5.3 \\
$\quad$ Nonirrigated area & 6.5 & 3.9 \\
Average water use $\left(\mathrm{m}^{3} / \mathrm{ha}\right)$ & 6750 & 6870 \\
Water tariff $(€ / \mathrm{ha})$ & 96.6 & 94.5 \\
\hline
\end{tabular}

In this expression, the left-hand side represents the marginal value of resources used for producing a unit of the $j r$ activity, while the right-hand side can be interpreted as the marginal profit of this activity.

[38] In the second step of the procedure, the vector $\mu_{j r}$ is employed to specify a nonlinear objective function such that the marginal costs of the model activities are equal to their respective revenues at the base year activity levels $x^{0}$. A quadratic cost function is assumed,

$$
C T_{j r}=\alpha_{j r} x_{j r}+\beta_{j r} x_{j r}^{2}
$$

using the first-order conditions, the vector of marginal values $\mu_{j r}$ allows us to estimate parameters $\alpha_{j r}, y$, and $\beta_{j r}$ for this function according to

$$
\begin{gathered}
c_{j r}+\mu_{j r}=\alpha_{j r}+2 \beta_{j r} x_{j r}^{0} \\
\text { with } \alpha_{j r}=c_{j r} \quad \forall j, r / x_{j r} \neq 0 \\
\text { and } \alpha_{j r}=\max \left\{c_{j r^{\prime}},\left(\left(p_{j} y_{j r}-p_{j} y_{j r^{\prime}}\right)+c_{j r^{\prime}}\right)\right\} \forall j, r / x_{j r}=0,
\end{gathered}
$$

where $r^{\prime}$ represents the subset of irrigation technologies that do not exist in the observed situation but could probably be part of the solution if the economic environment changes.
Equation (11) allows the calibration of unobserved technologies or activities, while simultaneously guaranteeing that those activities are not included in the base year solution. Once the cost functions have been recovered, the complete nonlinear model can be defined as

$$
\begin{aligned}
\operatorname{Max} \sum_{j} \sum_{r} & \left(\left(p_{j} y_{j r}\right) x_{j r}-\left(\alpha_{j r} x_{j r}+\beta_{j r}\left(x_{j r}+\sum_{r^{\prime}} x_{j r}\right)^{2}\right)\right. \\
& \left.-t \sum_{j} \sum_{r} w_{j r} x_{j r}\right)
\end{aligned}
$$

$$
\text { subject to } \sum_{j} \sum_{r} a_{i j r} x_{j r} \leq b_{i}
$$

$$
x_{j r} \geq 0
$$

The objective function (12) integrates a water tariff component to simulate cost recovery scenarios. In this term, $t$ is the cost recovery level, and $w$ is the water use per unit of production activity. This nonlinear model reproduces the activity levels observed for the base year situation and is able to simulate hypothetical cost recovery scenarios.

\section{Empirical Application}

The two-step procedure was modeled as an automatic calibration routine using the General Algebraic Modeling System modeling language [Brooke et al., 1998] in order to facilitate model replication in a large number of irrigation districts and to identify differing impacts of water pricing policies throughout the Spanish territory. The model results allow the modeler to anticipate the impacts of a volumetric

\begin{tabular}{|c|c|c|c|c|c|c|c|}
\hline \multirow{2}{*}{$\begin{array}{l}\text { Cropping } \\
\text { Activity }\end{array}$} & \multirow{2}{*}{$\begin{array}{l}\text { Irrigation } \\
\text { Method }\end{array}$} & \multicolumn{3}{|c|}{ Canal de Montijo } & \multicolumn{3}{|c|}{ Bajo Guadalquivir } \\
\hline & & Area (ha) & WU $\left(\mathrm{m}^{3} / \mathrm{ha}\right)$ & GM (e/ha) & Area (ha) & $\mathrm{WU}\left(\mathrm{m}^{3} / \mathrm{ha}\right)$ & GM (€/ha) \\
\hline Rice & surface irrigation & 253 & 20,313 & 1211 & - & - & - \\
\hline Corn & surface irrigation & 2687 & 10,625 & 924 & 1093 & 7812 & 1921 \\
\hline Cereals & surface irrigation & 1970 & 2656 & 1029 & 3747 & 2344 & 910 \\
\hline Oilseeds & surface irrigation & 1849 & 3684 & 902 & 13,739 & 2812 & 987 \\
\hline Set aside & no irrigation & 651 & 0 & 429 & 1858 & & 447 \\
\hline Sugar beet & surface irrigation & 434 & 8594 & 1847 & 6422 & 4688 & 1746 \\
\hline Cotton & surface irrigation & - & - & - & 16,966 & 12,500 & 2311 \\
\hline Fodder crops & surface irrigation & 455 & 10,469 & 1095 & - & - & - \\
\hline Potato & surface irrigation & - & - & - & 691 & 3125 & 1845 \\
\hline Vegetables & surface irrigation & 1162 & 8594 & 528 & 297 & 4688 & 6598 \\
\hline Fruit trees & drip irrigation & 626 & 6250 & 3517 & 1041 & 10,156 & 8991 \\
\hline Citrus & surface irrigation & - & - & - & 552 & 9375 & 6356 \\
\hline Olive grove & drip irrigation & - & - & - & 1477 & 7812 & 1343 \\
\hline
\end{tabular}
water tariff on quantity and quality of water resource trends while assessing the impact on social and economic indicators, such as farm income and labor.

A comprehensive database was built using information from agricultural or river basin statistical sources [Ministerio de Agricultura Pesca y Alimentación (MAPA),

Table 2. Cropping Pattern, Water Used, and Gross Margin per Crop ${ }^{\mathrm{a}}$

${ }^{\mathrm{a}} \mathrm{WU}$, water used; GM, gross margin per crop. 
Table 3. Effect of a 6 Cents $€ / \mathrm{m}^{3}$ Water Price on Cropland Allocation

\begin{tabular}{|c|c|c|c|c|}
\hline & \multicolumn{2}{|c|}{ Canal de Montijo } & \multicolumn{2}{|c|}{ Bajo Guadalquivir } \\
\hline & $\begin{array}{l}\text { Water Price: } \\
0 \text { Cents } \mathrm{E} / \mathrm{m}^{3}\end{array}$ & $\begin{array}{l}\text { Water Price: } \\
6 \text { Cents } \mathrm{C} / \mathrm{m}^{3}\end{array}$ & $\begin{array}{l}\text { Water Price: } \\
0 \text { Cents } € / \mathrm{m}^{3}\end{array}$ & $\begin{array}{l}\text { Water Price: } \\
6 \text { Cents } € / \mathrm{m}^{3}\end{array}$ \\
\hline \multicolumn{5}{|c|}{ Cropland allocation (ha) } \\
\hline Rice & 253 & 0 & 0 & 0 \\
\hline Corn & 2687 & 1669 & 1494 & 1384 \\
\hline Oilseeds & 1849 & 2579 & 15,777 & 17,137 \\
\hline Set aside & 651 & 1287 & 1944 & 2136 \\
\hline Sugar beet & 434 & 375 & 6186 & 6033 \\
\hline Cotton & 0 & 0 & 16,299 & 14,389 \\
\hline Fodder crops & 455 & 346 & 0 & 0 \\
\hline Potato & 0 & 0 & 699 & 704 \\
\hline Olive grove & 0 & 0 & 1264 & 1264 \\
\hline Total area & 10,087 & 10,087 & 47,883 & 47,883 \\
\hline \multicolumn{5}{|l|}{ Farm net income } \\
\hline Total $(€)$ & $10,263,934$ & $7,566,015$ & $84,544,619$ & $61,498,052$ \\
\hline Average $(€ / h a)$ & 1018 & 750 & 1766 & 1284 \\
\hline \multicolumn{5}{|l|}{ Water use } \\
\hline Total $\left(\mathrm{m}^{3}\right)$ & $68,130,212$ & $39,970,026$ & $336,504,965$ & $237,284,685$ \\
\hline Average $\left(\mathrm{m}^{3} / \mathrm{ha}\right)$ & 6754 & 3963 & 7028 & 4956 \\
\hline
\end{tabular}

2000; Ministerio de Medio Ambientev (MMA), 2000]. For each irrigation district, available information was collected about observed production activity levels, irrigation technology, input use per crop, water charges, variable costs per activity, crop prices, crop yields, and agricultural policy subsidies. Total cropland, irrigated land, and water availability were also recorded for each irrigation district.

The model simulates farmers' responses to increasing water prices at the irrigation district level. To minimize the economic impact of water price, farmers can adopt different strategies depending on their water situation, technology, and agricultural patterns: First, farmers can alter the crop mix toward a higher proportion of less waterintensive crops; second, they can adopt water-conserving technologies; third, they can switch to more extensive production; and fourth, farmers can reduce total irrigated land, increasing the proportion of dry-land crops. These responses are all aimed at minimizing the reduction in farm net income resulting from an increase in water price. The model endogenously simulates all four options, and in general, a combination of responses can be found. This metamodel allowed us to analyze the economic impacts of cost recovery scenarios on cropland allocation, irrigation technologies, water use, farm net income, employment, and the water agency revenue.

In order to illustrate the capabilities of this methodological approach in assessing the implementation of water pricing mechanisms, the results obtained for two particular gravity irrigation districts are discussed. One of the irrigation districts, Canal de Montijo, is located in the Guadiana River basin in central Spain, and the other, Bajo Guadalquivir, pertains to the Guadalquivir River basin in southern Spain. In both cases, irrigation is carried out with surface water; the river basin authority takes the major responsibil-
Canal de Montijo

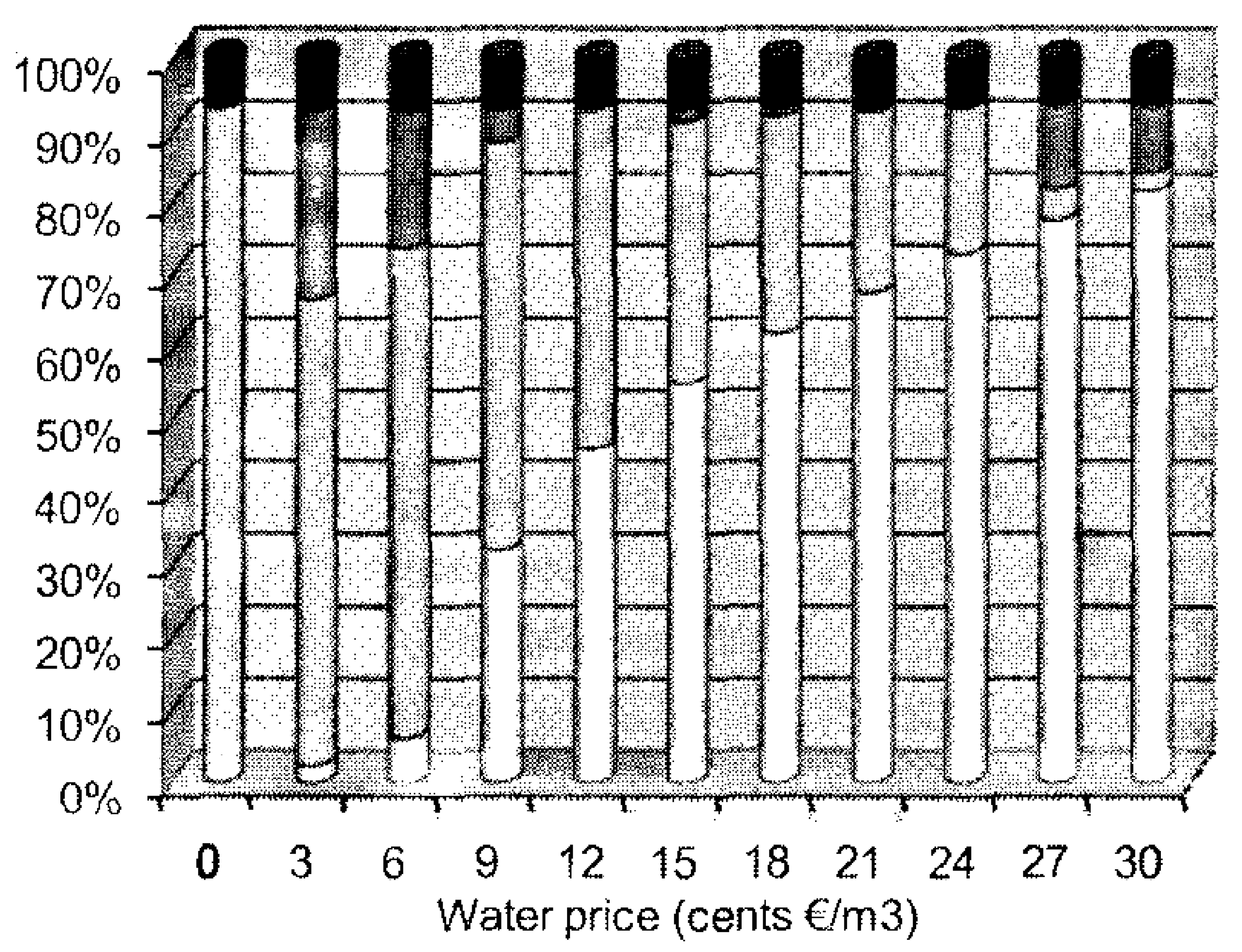

Bajo Guadalquivir

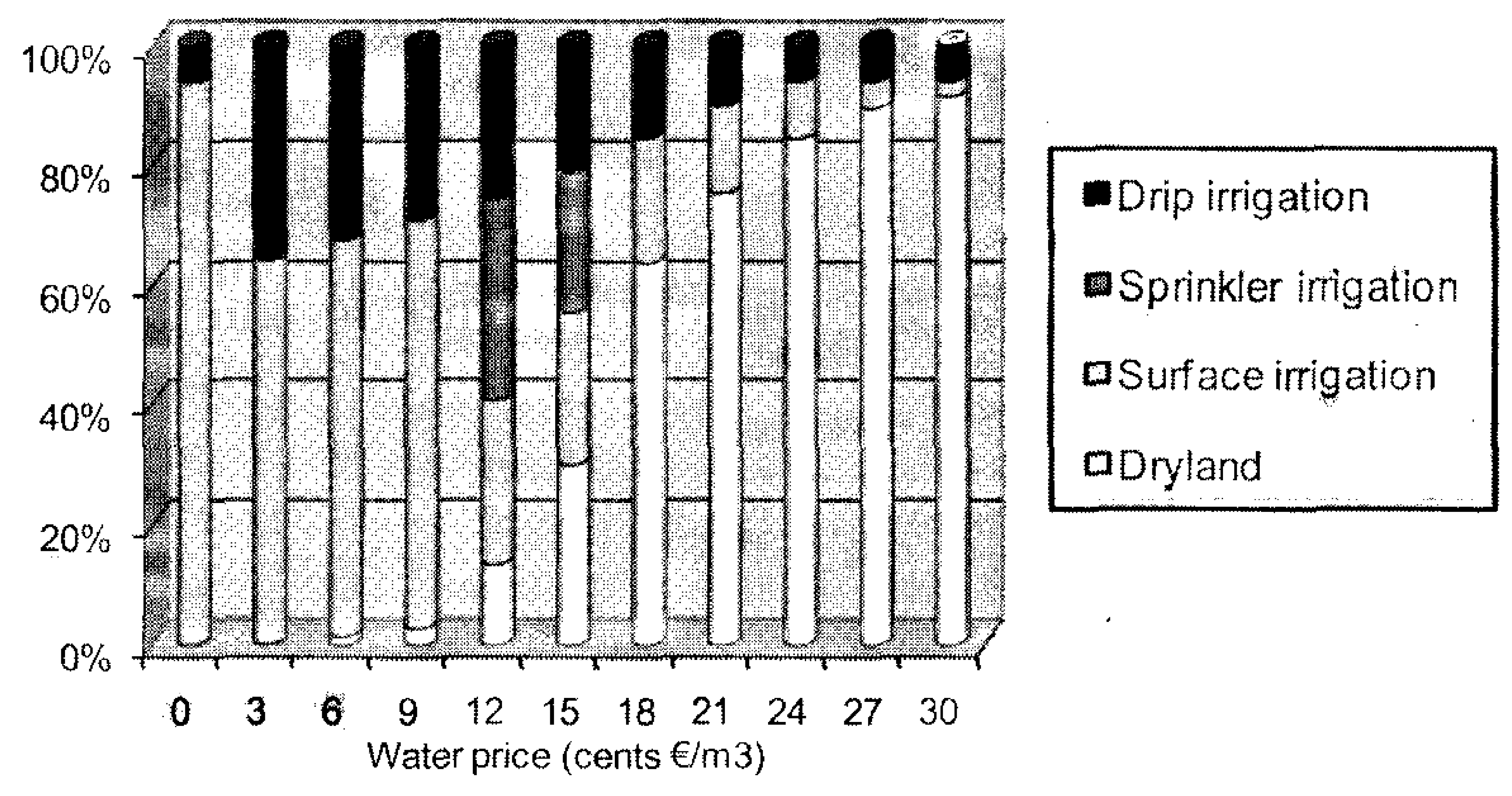

Figure 1. (a) Canal de Montijo irrigation technology and (b) Bajo Guadalquivir irrigation technology.

See color version of this figure in the HTML. 


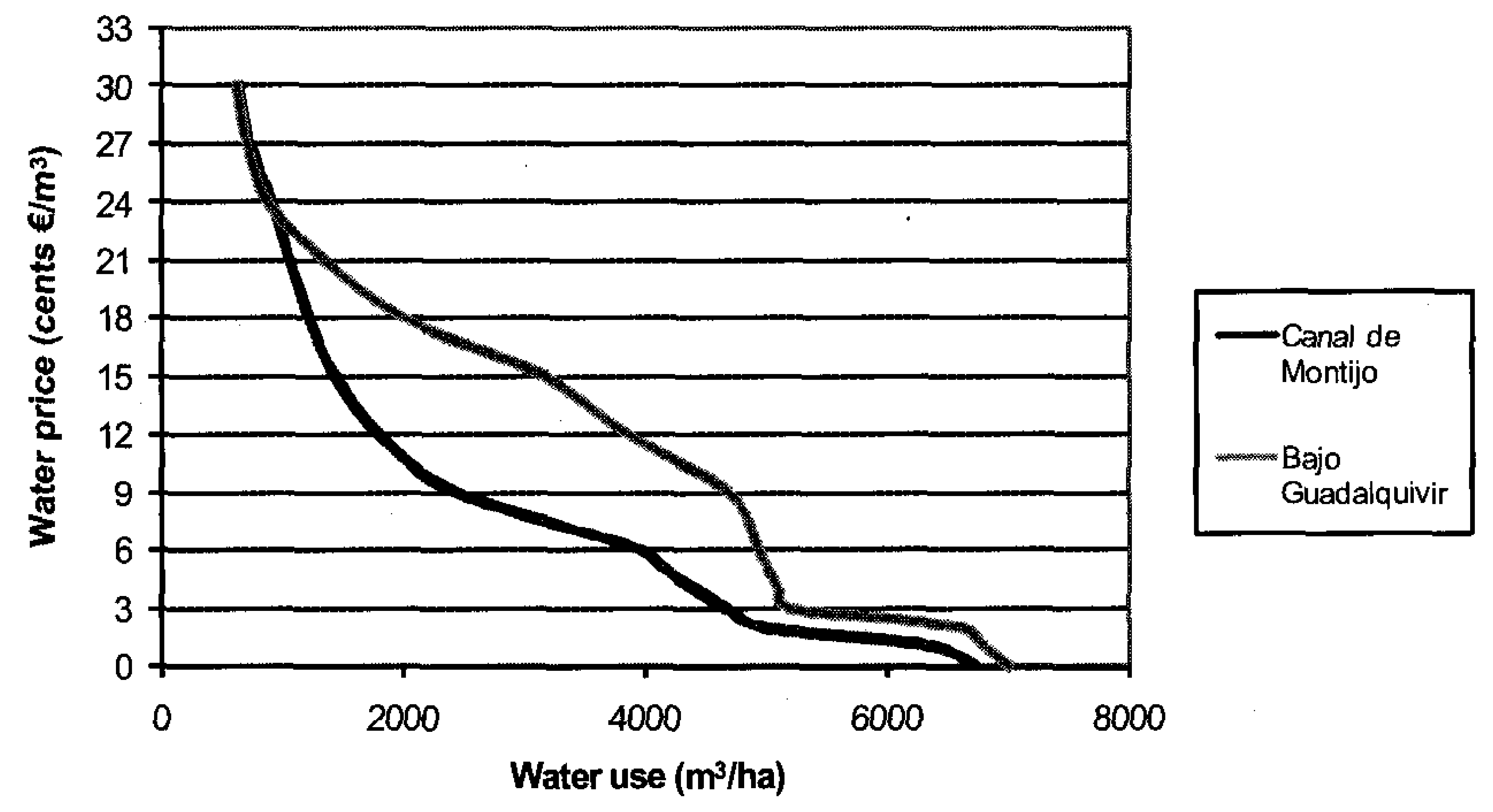

Figure 2. Water consumption. See color version of this figure in the HTML.

ity for operation, maintenance, and management of the water delivery system, and farmers are charged on a perunit area basis. Main agronomic and economic characteristics are shown in Tables 1 and 2.

The mathematical programming model is calibrated for the base scenario that corresponds to the current situation where farmers pay a zero volumetric water price. The current water rate in both districts is established on a perhectare basis and its conversion to a volumetric price would represent 1.4 cents $€ / \mathrm{m}^{3}$.

According to the national report on cost recovery $[M M A, 2007]$, water rates related to water services ranged between 1 and 30 cents $€ / \mathrm{m}^{3}$ (expressed as an equivalent volumetric price), while average costs of water services amounted to 8 cents $€ / \mathrm{m}^{3}$ in 2002. On average, cost recovery level represented $87 \%$ among agricultural users. The corresponding cost recovery levels in Guadalquivir and Guadiana river basins represented 79 and $90 \%$, respectively.

However, reporting on cost recovery is subject to important limitations in the available information, and the resulting numbers are highly dependent on the valuation criteria and the user cost share coefficients established under Spanish law [MMA, 2007]. For instance, cost recovery rates would be notably lower if capital substitution costs were included [MAPA, 2000].
Other sources point out that current water rates are well below the financial costs [MMA, 2000; López Unzu and Rodriguez Ferrero, 2005]. According to $M M A$ [2000], water rates represent only a small portion of the state water budget and scarcely cover the staff costs of the responsible water agencies. In the same strand, López Unzu and Rodríguez Ferrero [2005] conclude that the application of valuation criteria as established under Spanish law results in very low levels of cost recovery. These authors analyze 11 investment projects included in the Irrigation National Plan and report large divergences among cost recovery rates and water prices as established by law. For the case of Bajo Guadalquivir irrigation district, the cost recovery rate would amount to 15.4 cents $€ / \mathrm{m}^{3}$, while water prices according to valuation criteria established under Spanish law would only represent 1.01 cents $€ / \mathrm{m}^{3}$.

In order to analyze the potential impact of establishing a volumetric water rate, water prices ranging from 3 to 30 cents $€ / \mathrm{m}^{3}$ have been simulated. We simulate water prices far above the target cost recovery level in order to assess different water pricing criteria and to illustrate the shadow price of water.

Table 3 illustrates changes in cropland allocation when a water price of 6 cents $€ / \mathrm{m}^{3}$ is applied in the Canal de Montijo (Guadiana River basin) and Bajo Guadalquivir (Guadalquivir River basin) irrigation districts, respectively.

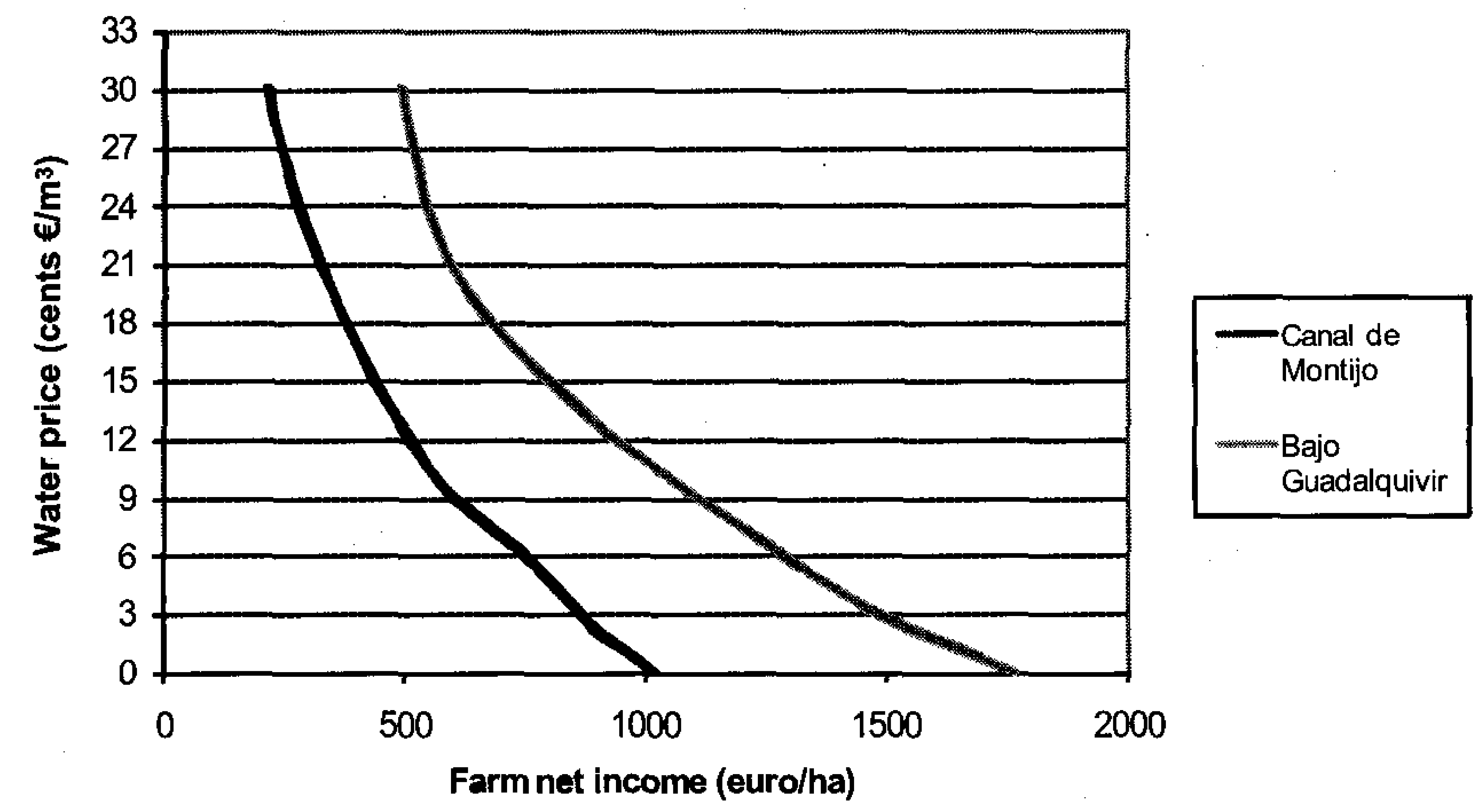

Figure 3. Farm net income. See color version of this figure in the HTML. 


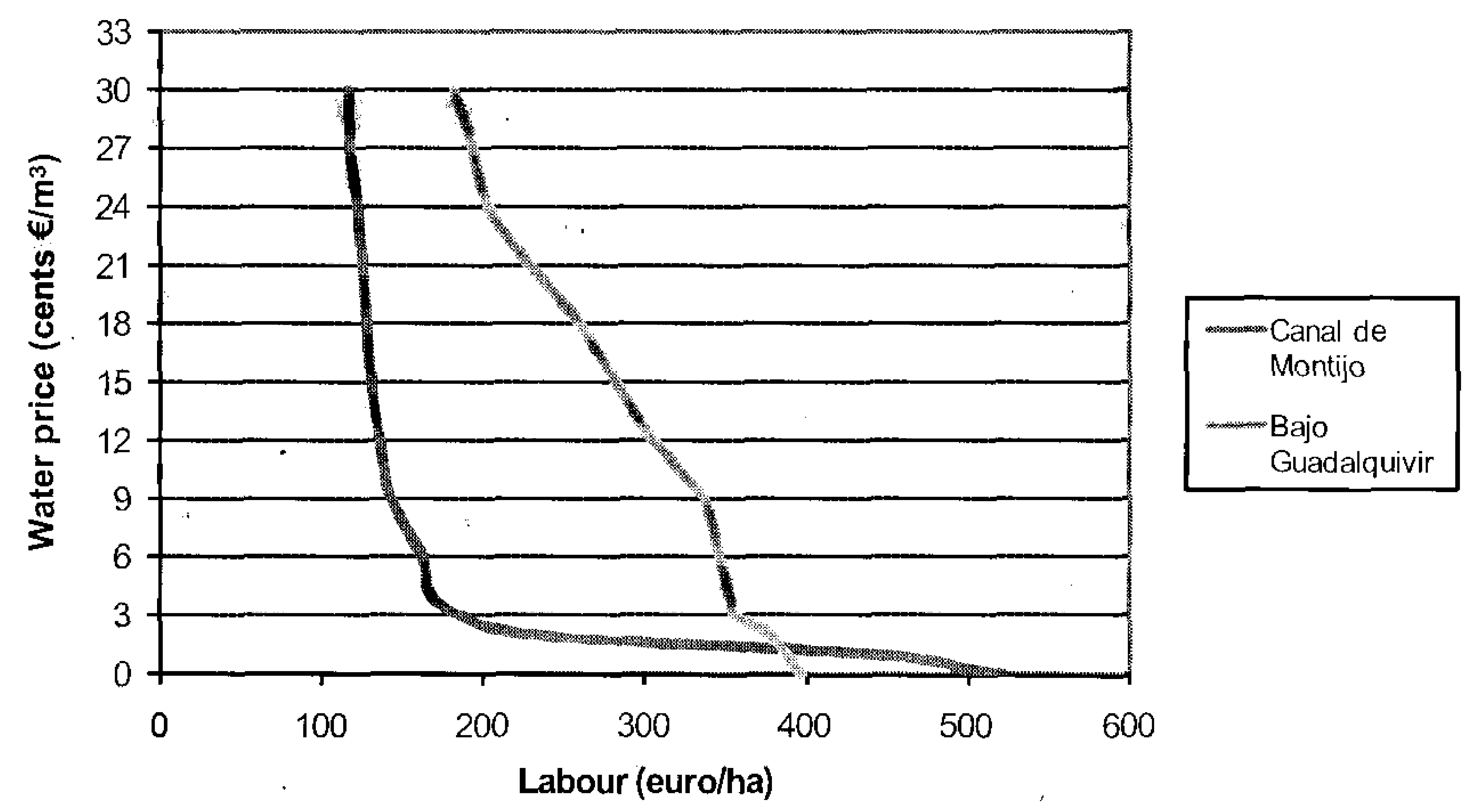

Figure 4. Labor. See color version of this figure in the HTML.

Results show that an increase in water price induces farmers to switch cropping patterns to less water-intensive crops in comparison with the base scenario. In the Canal de Montijo irrigation district, for instance, a water price of 6 cents $/ \mathrm{m}^{3}$ induces a partial substitution of water-intensive crops (rice and corn) with water-extensive crops (cereal and sunflower). The increase in set-aside land is a result of agricultural policy constraints that impose a set-aside requirement on cereals and oilseed crops.

The impact of water prices shows remarkable differences across irrigation districts for the case of vegetable production. In Canal de Montijo, farmers grow a low-valued tomato crop with large water requirements which explains the adverse impact of water price on vegetable crops. A very different effect occurs in Bajo Guadalquivir where vegetable production corresponds to high-valued crops.

In the Bajo Guadalquivir irrigation district, increasing water price from zero to 6 cents $€ / \mathrm{m}^{3}$ would not induce significant crop substitution effects. In this case, technology change is the main adaptation strategy adopted by farmers. As Figure 1 shows, in the base situation, surface irrigation is the predominant technology in both irrigation districts, while drip irrigation is only used for the fruit trees. As water price increases, farmers adopt water-saving technologies, switching from surface irrigation to sprinkler and drip irrigation methods. According to model results, a water price of 3 cents $€ / \mathrm{m}^{3}$ ought to result in a significant technological change (a change to sprinkler irrigation in the Canal de Montijo irrigation district and to drip irrigation in the Bajo Guadalquivir irrigation district).

Results on water abstraction show that an increase in water price from zero to 3 cents $€ / \mathrm{m}^{3}$ would result in a significant reduction of water use because of technological change and crop substitution effects. For example, in the Canal de Montijo irrigation district, a level of 3 cents $€ / \mathrm{m}^{3}$ induces a reduction in water use of $30 \%$, while a level of 6 cents $€ / \mathrm{m}^{3}$ induces a reduction in water use of $40 \%$. For water prices higher than 6 cents $€ / \mathrm{m}^{3}$, water would be mainly allocated to high-added value crops, such as fruit trees and vegetables.

Regarding price clasticity, we observe that in the Canal de Montijo irrigation district, water demand would be inelastic up to 9 cents $€ / \mathrm{m}^{3}$ (see Figure 2). In contrast, in the Bajo Guadalquivir irrigation district, water demand would be inclastic up to 15 cents $\mathrm{C} / \mathrm{m}^{3}$, showing the greater productivity differential between irrigated and dry-land crops.

Even if water demand is fairly inelastic for water prices ranging from zero to 6 cents $€ / \mathrm{m}^{3}$ in both irrigation districts, the price responsiveness of water demand may

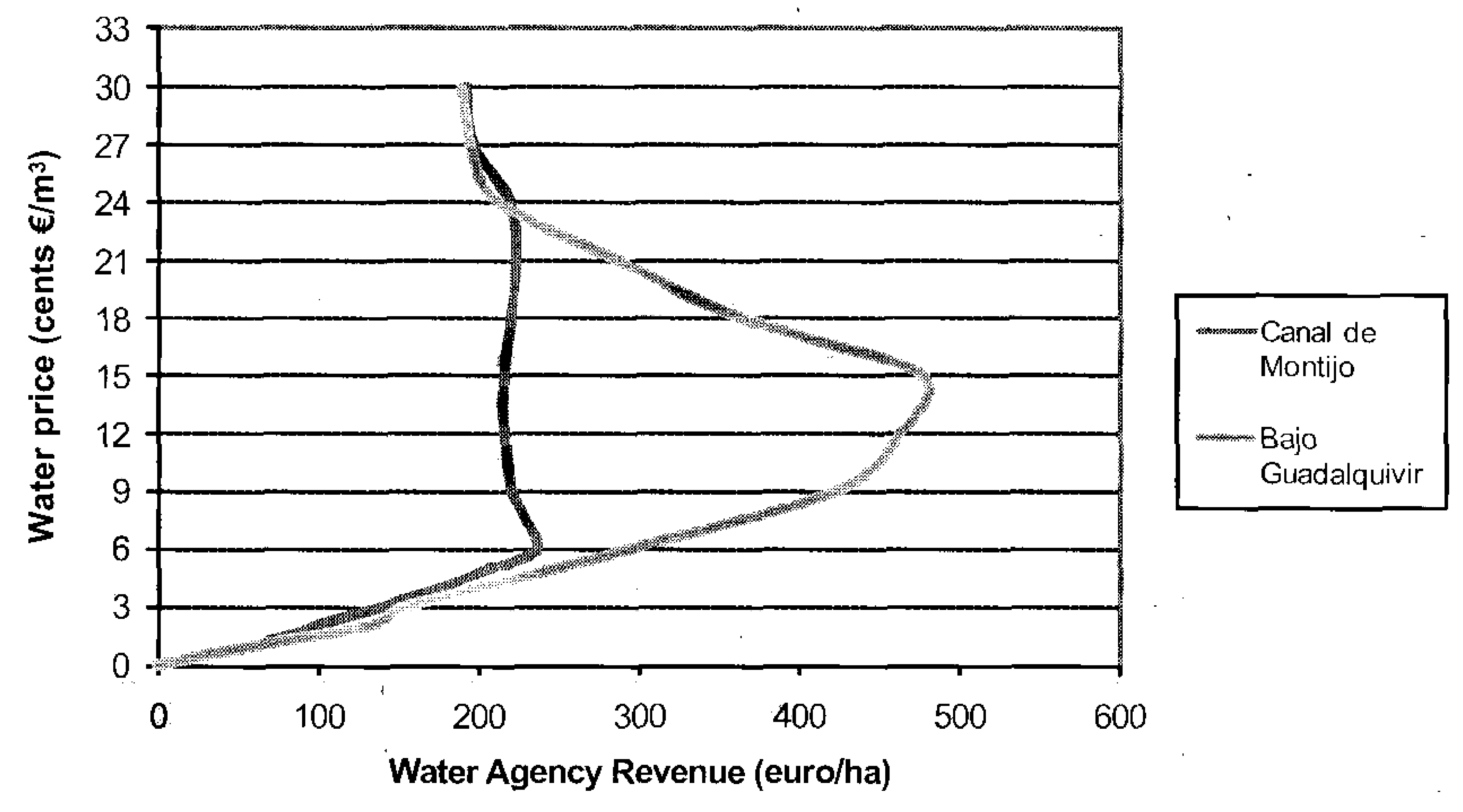

Figure 5. Water agency revenue. See color version of this figure in the HTML. 


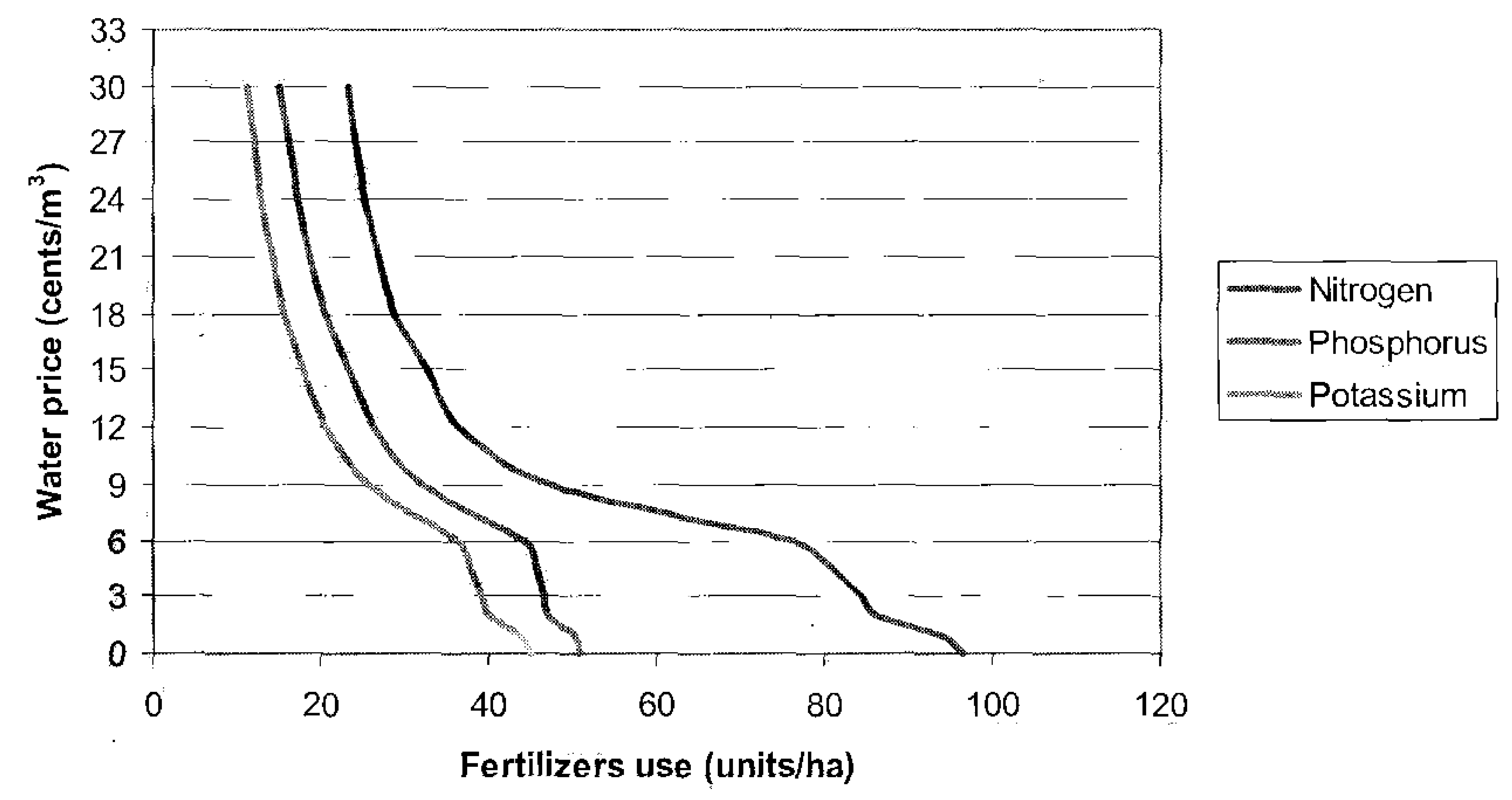

Figure 6. Fertilizer consumption in Canal de Montijo irrigation district. See color version of this figure in the HTML.

seem rather high compared to previous studies. However, it is important to point out that many previous studies of agricultural water demand rely on short-run response. While Moore et al. [1994] found a low price elasticity in the short run, they do find a larger intermediate and long-run elasticity. In our case, several factors may explain the responsiveness to this relatively high elasticity value. First, the favorable agroclimatic conditions in these districts allow the farmer to grow a wide range of crops and thus may adopt crop substitution strategies to reduce water consumption. Second, there are large water quotas and surface irrigation predominates in the base scenario. This is why technology adoption may play an important role in reducing water consumption. Schoengold et al. [2006] also show that the price elasticity of water demand might be greater than previous studies have shown when considering changes in irrigation technology.

Socio-economic effects, mainly farm income and labor, of water pricing policies are also analyzed (see Figures 3 and 4). Regarding farm income, the negative impact is partially mitigated by the adjustment made in response to water price increase. The result is a smaller percentage decline in farm income than that in water use. In the Canal de Montijo irrigation district, for instance, a 3 cents $€ / \mathrm{m}^{3}$ water price induces a water use reduction of $30 \%$ while causing an income reduction of $15 \%$. In the same way, in the Bajo Guadalquivir irrigation district, a 3 cents $€ / \mathrm{m}^{3}$ water price induces a reduction in water use of $26 \%$ and an income reduction of $16 \%$.

The impact of water prices on labor is particularly important for low water price levels in the Canal de Montijo district. Figure 4 shows that water and labor exhibit important complementarities. This is particularly true for low water prices.

Figure 5 depicts water agency revenue for different water prices and reveals that reductions in water use and cost recovery may become conflicting objectives above a critical water price. In the Canal de Montijo irrigation district, the maximum level of water revenue will be attained with a water tariff of 6 cents $€ / \mathrm{m}^{3}$.

Figures 6 and 7 reveal the close correlation between fertilizer use and water abstraction. Regarding fertilizer use, model results are quite different for the two irrigation districts. In the Canal de. Montijo irrigation district (Figure 6), the amount of fertilizer used undergoes a significant reduction when water prices increase. This fact is particularly true for low water prices.

Regarding the Bajo Guadalquivir irrigation district (Figure 7), model results show that a water price increase may cause a rise in the amount of nitrate fertilizer used. This phenomenon occurs for medium water price levels and can be explained by the crop substitution effect. Actually, there

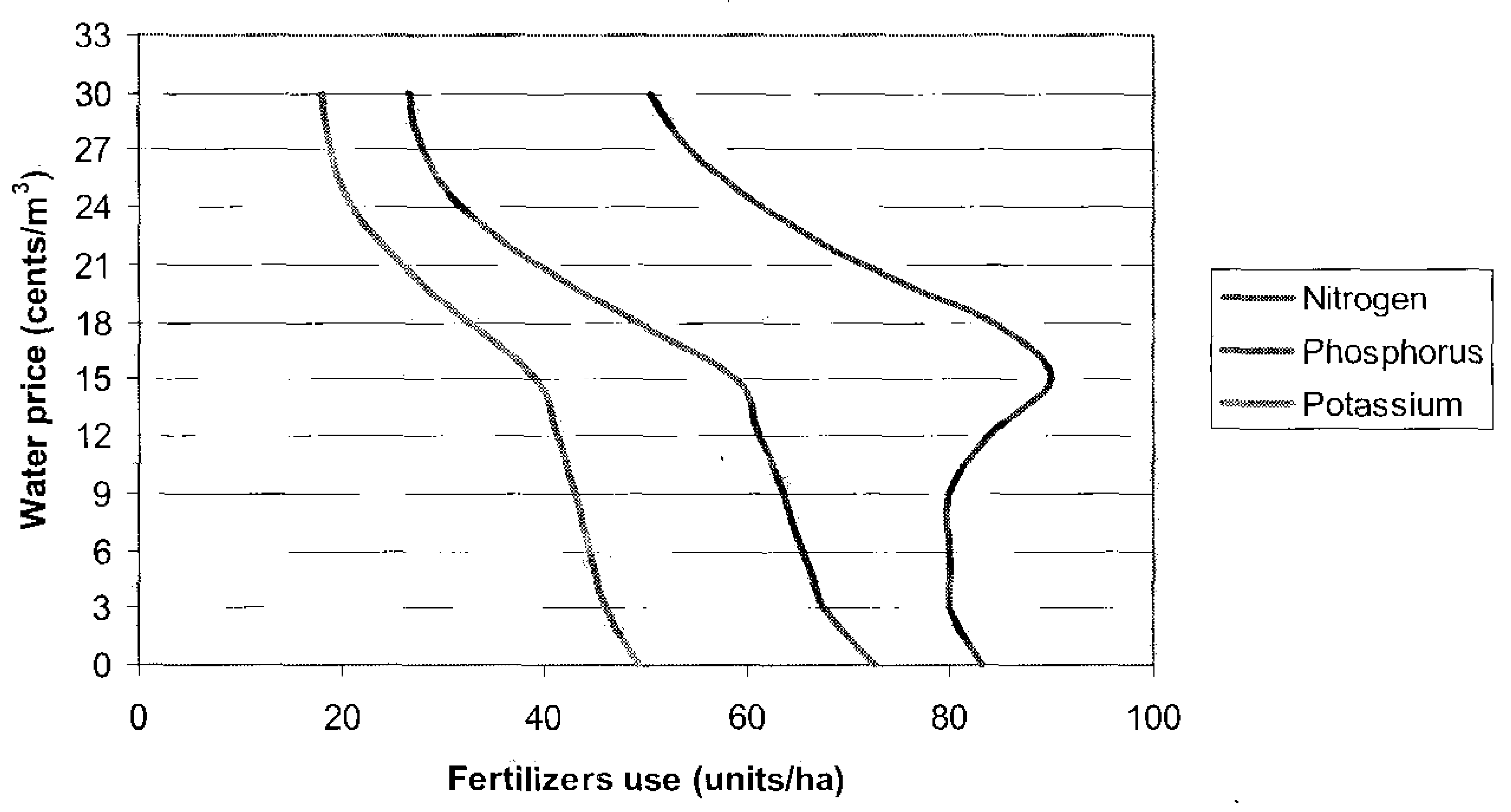

Figure 7. Fertilizer consumption in Bajo Guadalquivir irrigation district. See color version of this figure in the HTML. 
is a close correspondence between crop activities and fertilizer use, and the partial substitution of cotton with other crops with higher-nitrate fertilizer requirements, such as sugar beet, can explain this outcome. This result shows that the environmental impacts of water pricing mechanisms can differ greatly among different districts and require further analysis.

\section{Conclusions}

The cost recovery approach established in the Water Framework Directive poses an important challenge in Mediterranean countries like Spain where agricultural users traditionally pay very low water charges, as compared to other water users, and are charged on a per-unit area basis. Its implementation implies an important change in water policies and raises the need to carefully define water pricing criteria, taking into account the likely environmental, socioeconomic, or specific regional impacts. This context confers an important social value to the development of methodological tools that may convey detailed and disaggregated information to guide the design of water pricing. The aim of this paper is to develop a methodology to assess the environmental and socio-economic impacts of water pricing mechanisms in Spanish irrigated lands.

A positive mathematical programming model is developed to evaluate the impact of cost recovery in a large number of irrigation districts representing the heterogeneous characteristics that can be found throughout the Spanish territory. The proposed model allows farmers' behavior to be simulated under different water pricing scenarios. Compared to conventional farm modeling methodologies, the positive mathematical programming approach has lower field data collection requirements and exploits information in available statistical databases, making it easier to perform analyses both on a local and global river basin scale. One of the main limitations of positive mathematical programming is that options available to the farmers are limited to the observed activities in the base year situation. To overcome this difficulty, a cost transfer approach is proposed to simulate the adoption of new production activities and irrigation technologies.

Another important issue is that the model contains an automatic calibration procedure based on recorded production activity levels for each area. This approach shows two important advantages: (1) The model allows easy replication in a large number of irrigation districts which were selected throughout the Spanish territory, and (2) the model can be easily updated as new statistical observations become available each year. Both characteristics are important for water policy design.

Finally, an empirical application illustrates that model results convey specific and detailed information about the impact on water use, environmental indicators, crop allocation decisions, technology adoption, labor, output supply, farm income, and water agency revenues when different scenarios of cost recovery are considered. This may become useful information to guide the design of water pricing criteria.

These characteristics suggest that this modeling approach may be used as a management tool to assist in the implementation of the cost recovery approach as established in the new Water Framework Directive.
[65] Acknowledgments. We appreciate the helpful comments of the anonymous reviewers. Funds supporting this research come from the national research project "Integration of Environmental and Economic Criteria in Water Management" (Integración de Criterios Económicos y Ambientales en la Gestión del Agua 2004/03528), 2004-2007.

\section{References}

Brennan, D., S. Tapsuwan, and G. Ingram (2007), The welfare costs of urban outdoor water restrictions, Aust. J. Agric. Resour. Econ., 5l(3), 243-261, doi:10.1111/j.1467-8489.2007.00395.x.

Brooke, A., D. Kendrick, A. Meeraus, and R. Raman (1998), GAMS-A User's Guide, Gen. Algebraic Modell. Syst. Dev. Corp., Washington, D. C.

Caswell, M., and D. Zilberman (1985), The choices of irrigation technologies in California, Am. J. Agric. Econ., 67(2), 224-234, doi:10.2307/ 1240673.

Centre for International Economics (2004), Addressing water scarcity with charges, Queensland Dep. of Nat. Resour. and Mines, Canberra, Aust. Capital Territ.

Cornish, G., B. Bosworth, C. Perry, and J. Burke (2004), Water charging in irrigated agriculture: An analysis of international experience, Water Rep. 28, Food and Agric. Organ. of the U. N., Rome.

de Frahan, B. H., J. Buysse, P. Polomé, B. Fernagut, O. Harmignie, L. Lauwers, G. Van Huylenbroeck, and J. Van Meensel (2005), Positive mathematical programming for agricultural and environmental policy analysis: Review and practice, in Management of Natural Resources: $A$ Handbook of Operations, Research Models, Algorithms, and Implementations, edited by A. Weintraub et al., Springer, New York.

De Fraiture, C., and C. Perry (2002), Why is irrigation water demand irresponsive at low price ranges?, paper presented at World Bank Water Conference, Agadir, Morocco.

European Commission (2000), Directive 2000/60/EC of the European Parliament and of the Council, of 23 October 2000, establishing a framework for community action in the field of water policy, Off. J. Eur. Communities, L327, 1-72.

European Environmental Agency (2005), Agriculture and environment in EU-15-The IRENA indicator report, Rep. 6/2005, Copenhagen.

Gómez-Limón, J. A., and L. Riesgo (2004), Water pricing: Analysis of differential impacts on heterogeneous farmers, Water Resour. Res., 40, W07S05, doi: 10.1029/2003WR002205.

Green, G., D. Sundig, D. Zilberman, and D. Parker (1996), Explaining irrigation technology choices: A microparameter approach, Am. J. Agric. Econ., 78(4), 1064-1072, doi:10.2307/1243862.

Heckelei, T., and W. Britz (2000), Positive mathematical programming with multiple data points: Across-sectional estimation procedure, Cah. Econ. Soc. Rurales, 57, 28-50.

Heckelei, T., and H. Wolff (2003), Estimation of constrained optimisation models for agricultural supply analysis based on generalised maximum entropy, Eur. Rev. Agric. Econ., 30(1), 27-50, doi:10.1093/erae/30.1.27.

Howitt, R. E. (1995), Positive mathematical programming, Am. J. Agric. Econ., 77(2), 329-342, doi:10.2307/1243543.

Iglesias, E., A. Garrido, and A. Gómez-Ramos (2003), Evaluation of drought in irrigated areas, Agric. Econ., 29(2), 211-229, doi:10.1111/ j.1574-0862.2003.tb00158.x.

Iglesias, E., A. Garrido, and A. Gómez-Ramos (2007), Economic drought management index to evaluate water institutions' performance under uncertainty, Aust. J. Agric. Resour. Econ., 51(1), 17-38, doi:10.1111/ j.1467-8489.2007.00361.x.

Johansson, R. C., J. Tsur, T. L. Roe, R. Doukkali, and A. Dinar (2002), Pricing irrigation water: A review of theory and practice, Water Policy, 4 , 173-199, doi:10.1016/S1366-7017(02)00026-0.

Jones, T. (2003), Pricing water, OECD Obs., 236

Kuehne, G., and H. Bjornlund (2007), One size does not fit all-Recognizing heterogeneity in Australian farmers, paper presented at Fourth International Conference on Irrigation and Drainage, U.S. Soc. for Irrig. and Drain. Prof., Sacramento, Calif., 3-6 Oct.

López Unzu, F., and N. Rodríguez Ferrero (2005), Eficiencia económica de las nuevas obras del plan hidrológico para el regadío en la cuenca del Guadalquivir, Rev. Estud. Reg., 73, 159-181.

Martínez, Y., and J. Albiac (2004), Agricultural pollution control under Spanish and European environmental policies, Water Resour. Res., 40, W10501, doi:10.1029/2004WR003102.

Maybery, D., L. Crase, and C. Gullifer (2005), Categorising farming values as economic, conservation and lifestyle, J. Econ. Psychol., 26, 59-72, doi:10.1016/j.joep.2003.10.001.

Ministerio de Agricultura Pesca y Alimentación (MAPA) (2000), Plan nacional de regadíos, Madrid. 
Ministerio de Medio Ambiente (MMA) (2000), Libro blanco del agua en España, Madrid.

Ministerio de Medio Ambiente (MMA) (2007), Precio y costes de los servicios del agua en España, in Informe Integrado de Recuperación de Costes de los Servicios de Agua en España, Artículo 5 y Anejo III de la Directiva Marco del Agua, Madrid.

Moore, M. R., N. R. Gollehon, and M. B. Carey (1994), Multicrop production decisions in western irrigated agriculture: The role of water price, Am. J. Agric. Econ., 76(4), 859-874, doi:10.2307/1243747.

Musgrave, W. F. (2000), The political economy of water price reforms in Australia, in The Political Economy of Water Pricing Reforms, edited by A. Dinar, pp. 299-321, Oxford Univ. Press, New York.

National Research Council (2001), Envisioning the Agenda for Water Resources Research in the Twenty-First Century, Natl. Acad. Press, Washington, D. C.

Organisation for Economic Cooperation and Development (OECD) (1999), The price of water: Trends in OECD countries, executive summary, Paris.

Organisation for Economic Cooperation and Development (OECD) (2001), Methods and results: Executive summary, in Environmental Indicators for Agriculture, vol. 3, Organ. Econ. Coop. Dev., Paris.

Paris, Q., and R. Howitt (1998), An analysis of ill-posed production problems using maximum entropy, Am. J. Agric. Econ., 80(1), 124-138, doi: $10.2307 / 3180275$.

Preckel, P. V., D. Harington, and R. Dubman (2002), Primal/dual positive math programming illustrated through an evaluation of the impact of market resistance to genetically modified grains, Am. J. Agric. Econ., 84(3), 679-690, doi:10.1111/1467-8276.00327.

Röhm, O., and S. Dabbert (2003), Integrating agri-environmental programs into regional production models: An extension of positive mathematical programming, Am. J. Agric. Econ., 85(1), 254-265, doi:10.1111/14678276.00117 .

Scheierling, S. (1995), Overcoming agricultural pollution of water: The challenge of integrating agricultural and environmental policies in the European Union, Tech. Pap. 269, World Bank, Washington, D. C.
Scheierling, S. M., J. B. Loomis, and R. A. Young (2006), Irrigation water demand: A meta-analysis of price elasticities, Water Resour. Res., 42, W01411, doi:10.1029/2005WR004009.

Schoengold, K., D. L. Sunding, and G. Moreno (2006), Price elasticity reconsidered: Panel estimation of an agricultural water demand function, .Water Resour. Res., 42, W09411, doi:10.1029/2005WR004096.

Tsur, Y. (2000), Water regulation via pricing: The role of implementation costs and asymmetric information, in The Political Economy of Water Pricing Reforms, edited by A. Dinar, pp. 105-120, Oxford Univ. Press, New York.

Tsur, Y., and A. Dinar (1997), On the relative efficiency of alternative methods for pricing irrigation water and their implementation, World Bank Econ. Rev., 11, 243-262.

Varela-Ortega, C., J. M. Sumpsi, A. Garrido, M. Blanco, and E. Iglesias (1998), Water pricing policies, public decision making and farmers' response: Implications for water policy, Agric. Econ., 19(1-2), 193-202, doi:10.1016/S0169-5150(98)00048-6.

Vogel, S. (1996), Farmers' environmental attitudes and behavior: A case study for Austria, Environ. Behavior, 28(5), 591-613, doi:10.1177/ 001391659602800502.

Willock, J., I. J. Deary, G. Edward-Jones, G. J. Gibson, M. J. McGregor, A. Sutherland, J. B. Dent, O. Morgan, and O. Grieve (1999), The role of attitudes and objectives in farmer decision making: Business and environmentally oriented behaviour in Scotland, J. Agric. Econ., $50(2), 286-303$.

Xabadia, A., R. Goetz, and D. Zilberman (2004), Optimal dynamic pricing of water in the presence of water logging and spatial heterogeneity of land, Water Resour. Res., 40, W07S02, doi:10.1029/2003WR002215. 